\title{
Effect of Organic Manures and Chemical Fertilizers on the Yield of Rice Seed "Lalat"
}

\author{
L.C. Naorem* \\ Central Research Station in Farming System Research, OUAT, Bhubaneswar, India \\ *Corresponding author
}

\section{A B S T R A C T}

\begin{tabular}{|l|}
\hline Ke y w o r d s \\
$\begin{array}{l}\text { Rice seed, Lalat, Organic } \\
\text { manures, Chemical } \\
\text { fertilizers }\end{array}$ \\
\hline Article Info \\
\hline $\begin{array}{l}\text { Accepted: } \\
\text { 15 September } 2018 \\
\text { Available Online: } \\
\text { 10 October } 2018\end{array}$ \\
\hline
\end{tabular}

\section{Introduction}

Rice (Oryza sativa) is one of the most important food crops of India in term of area, production and consumer preference. It provides over $21 \%$ of the calorific needs of the world's population and upto $76 \%$ of the calorific intake of the population of South East Asia. It is one of the main sources of carbohydrate and also contains considerable amount of protein, minerals and vitamins. India is the second largest producer and consumer of rice in the world.

In Orissa rice is synonymous with food; agriculture in Orissa to considerable extent means growing rice. Rice covers about 69 percent of cultivated area and is the major crop covering about 63 percent of total area under food grains. It is the staple food of almost entire population of Orissa and therefore, the state economy is directly linked with the improvement in production and productivity of rice in the state.

Today, global agriculture is at crossroads as a consequence of climatic change, increased population pressure and detrimental environmental impacts. Increased population needs more food to live on the Earth. India is an agricultural country. Indian population has already crossed 125 crores and it ranks second position in the world. The food production should be increased with the geometrically growing population. In India, there is a constant pressure on crop production from 
available cultivable land with limited water resources in order to keep pace with the food requirements for an ever-increasing population. Application of suitable fertilizers is one of the ways to attain maximum crop yield. Chemical fertilizer is the major supplier of nutrients besides organic and green manures. The use of chemical fertilizers has been kingpin of modern agriculture. This undoubtedly boosted the food production but at the same time, it shows the negative effects on physio-chemical properties of soil, nitrogen transformation, macro and micronutrient uptake and nutritional composition (Mahesh and Hosmani, 2004). Application of suitable fertilizers is one of the ways to attain maximum crop yield. Chemical fertilizer is the major supplier of nutrients besides organic and green manures. The production of rice is however, facing a sustainability problem due to practices of modern production system with indiscriminate use of chemical fertilizers and pesticides (Duxbury et al., 2000; Ladha et al., 2000). Hence, the present study was planned with an objective to investigate the effect of selected organic manures and chemical fertilizer on the yield of Rice seed "Lalat".

\section{Materials and Methods}

\section{Experimental design}

The experimental site was selected in Central Research Station, OUAT, Bhubaneswar. The experiment was designed with Randomised Block Design having 8 treatments and 3 replication. The treatments were as follows involving both chemical, biofertilizer, FYM, non-edible oil.

$\mathrm{T}_{1}$ : Different organic sources equivalent to $1 / 3$ of recommended N (1/3N as FYM@ 5.5t/ha; $1 / 3 \mathrm{~N}$ as Dhaincha, $1 / 3 \mathrm{~N}$ as NEO).

$\mathrm{T}_{2}: \mathrm{T}_{1}+$ agronomic practice for weed and pest control (without chemical pesticides)
$\mathrm{T}_{3}: 50 \% \mathrm{~N}$ as $\mathrm{FYM}+50 \% \mathrm{~N}$ as Azospirillum $+\mathrm{RP}+\mathrm{PSB}$

$\mathrm{T}_{4}: \mathrm{T}_{1}+$ Azospirillum $+\mathrm{PSB}$

$\mathrm{T}_{5}: 50 \% \mathrm{RDF}+50 \% \mathrm{~N}$ as FYM (8t/ha)

$\mathrm{T}_{6}: 100 \% \mathrm{NPK}$

$\mathrm{T}_{7}: 100 \% \mathrm{NPK}+25 \mathrm{Kg} \mathrm{ZnSO}_{4}$

$\mathrm{T}_{8}: \mathrm{T}_{7}+$ residue recycling

\section{Plot size}

$4.5 \mathrm{~m} \times 5 \mathrm{~m}$

\section{Incorporation of green manure Dhainca (Sesbania aculeta)}

Dhaincha at the rate of $25 \mathrm{~kg} /$ ha was sown 1 month before transplanting of rice crop in $\mathrm{T}_{1}$, $\mathrm{T}_{2}$ and $\mathrm{T}_{3}$. Prior to transplanting the dhaincha crop was incorporated into the soil.

\section{Raising of seedlings}

Seedlings were raised in wet nursery bed. Prior to sowing in the nursery beds, the seeds were soaked for 24 hours in water. After draining out the water, seeds were incubated for sprouting.

The seed rate used was $30 \mathrm{~kg} / \mathrm{ha}$. After $4^{\text {th }}$ day, $1-2 \mathrm{~cm}$ standing water was allowed in the nursery bed.

\section{Preparation of plot}

The field was thoroughly ploughed to make the soil well pulverized. Laddering was done for proper leveling of the plot.

Two drainage- cum- irrigation channels were prepared between the strips and bunds were raised around the main plot and each sub-plot. 


\section{Fertilizer application}

The major nutrients applied viz. nitrogen, phosphorus and potassium were applied as per recommendation $\left(80 \mathrm{~kg} \mathrm{~N}+40 \mathrm{~kg} \mathrm{P}_{2} \mathrm{O}_{5}+40\right.$ $\mathrm{kg} \mathrm{K} \mathrm{K}_{2} \mathrm{O} / \mathrm{ha}$ ). FYM 20t/ha applied 15 days in advance to avoid immobilization of nitrogen.

10 packets ( $2 \mathrm{~kg} / \mathrm{ha}$ ) each of Azospirillum and Phosphobacteria were mixed with $25 \mathrm{~kg}$ FYM and $25 \mathrm{~kg}$ of soil and mixture broadcasted uniformly in the main field before transplanting. Non edible neem seed cake @ $250-400 \mathrm{Kg}$ per hectare was applied as soil application.

\section{Transplanting}

21 days old seedlings were transplanted in the main field at a spacing of $20 \mathrm{~cm} \times 10 \mathrm{~cm}$ with 2-3 seedlings per hill.

\section{Irrigation}

After transplanting of seeds, flood irrigation was given to facilitate availability of enough moisture to the seeds to initiate the process of growth of the crop. Irrigation was given as and when required.

\section{Weeding and plant protection measures}

In order to keep the crop weed free, hand weeding was done. Prophylatic plant protection measures were adopted to protect the crop from diseases and pest attack.

\section{Harvesting}

When the crop approached harvestable maturity stage, the plants belonging to each treatment and replication were harvested separately. The harvested plants are threshed; seeds were cleaned, dried and graded. The graded seeds were weighed to compare the seed yield.

\section{Biometric observation}

\section{Panicle length}

The length of the effective panicles in the sample hills was measured from neck node to tip and was expressed in centimeter and the mean value was computed.

\section{Number of grains per panicle}

Total number of seeds formed in each panicle in sample hills was counted and the mean was computed.

\section{Fertile grains per panicle}

Number of filled seeds in each panicle in sample hills was counted and the mean computed.

\section{Sterile grains per panicle}

Number of chaffy/ empty seed in each panicle in sample hills was counted and the mean value computed.

\section{Seed yield per hectare}

The total seed yield in each replication on each treatment was determined. From the observation data, the seed yield per hectare was computed and expressed in $\mathrm{kg} / \mathrm{ha}$.

\section{Straw yield per hectare}

The total straw yield in each plot was recorded and the straw yield per hectare was computed and expressed in $\mathrm{kg} / \mathrm{ha}$.

\section{0 seed weight}

After harvest of the seed crops and completion of post-harvest operation, 1000 seeds were counted from each replication under each treatment. The weight of 1000 seeds was taken 
by an electronic balance and expressed in gram.

\section{Harvest index (HI)}

Harvest index is defined as the ratio of economic yield to the biological yield and it was calculated by using the formula given by Donald (1962)

Harvest index $(\%)=$ Grain yield $/$ Biological yield $\times 100$.

\section{Results and Discussion}

The data (Table 1 and 2) indicated that the Maximum panicle length of 27.82 was obtained in $\mathrm{T}_{8}$ Similar results have been obtained by Muhammad et al., 2014 in rice. Highest grain/panicle was observed in $\mathrm{T}_{7}$ (145.67).The findings were agreement with Yadav et al., 2010 in hybrid rice. Maximum number of fertile grain/panicle was obtained from $\mathrm{T}_{7}$ (78.10). This confirms the study of Tabar Y.S 2012 and Mahajan et al., 2012 in rice whereas maximum sterile grain/panicle was observed in $\mathrm{T}_{5}$ (26.33).

The highest test weight was 26.17 g per 1000 seeds in $\mathrm{T}_{7}$ and lowest was $22.63 \mathrm{~g}$ per 1000 seeds in $\mathrm{T}_{5}$. The present result is also in conformity with Muhammad et al., (2014) but contradicts the findings of Singh et al., (2000), Singh et al., (2009), Yadav et al., (2009), Kumari et al., (2010) in rice with organic source of nutrient management.

Table.1 Effect of organic crop management practices on yield attributing characters

\begin{tabular}{|c|c|c|c|c|c|}
\hline Treatments & $\begin{array}{l}\text { Panicle } \\
\text { length } \\
(\mathrm{cm})\end{array}$ & $\begin{array}{l}\text { Grain } \\
\text { /panicle }\end{array}$ & $\begin{array}{l}\text { Fertile } \\
\text { grain } \\
\text { /panicle }\end{array}$ & $\begin{array}{l}\text { Sterile } \\
\text { grain } \\
\text { /panicle }\end{array}$ & $\begin{array}{l}1000 \text { grain } \\
\text { wt.(gm) }\end{array}$ \\
\hline $\begin{array}{l}\mathrm{T}_{1^{-}} \text {(Different organic } \\
\text { sources equivalent to } 1 / 3 \text { of } \\
\text { recommended } \mathrm{N}(1 / 3 \text { as } \mathrm{FYM} \\
\text { @ } 5.5 \mathrm{t} / \mathrm{ha}, 1 / 3 \quad \mathrm{~N} \text { as } \\
\text { Dhaincha, } 1 / 3 \mathrm{~N} \text { as } \mathrm{NEO})\end{array}$ & 25.61 & 110.53 & 74.83 & 23.47 & 23.00 \\
\hline $\begin{array}{l}\mathrm{T}_{2}-\mathrm{T}_{1}+\text { Agronomic } \\
\text { practices for weed and pest } \\
\text { control (Without chemical) } \\
\end{array}$ & 26.02 & 125.93 & 77.20 & 22.57 & 24.67 \\
\hline $\begin{array}{l}\mathrm{T}_{3^{-}} \mathbf{5 0} \% \mathrm{~N} \text { as } \mathrm{FYM}+\mathbf{5 0} \% \mathbf{N} \\
\text { as Azospirillum }+\mathbf{R P}+\mathbf{P S B}\end{array}$ & 23.43 & 110.53 & 73.93 & 25.62 & 22.86 \\
\hline$\overline{\mathrm{T}_{4}-\mathrm{T}_{1}+\text { Azospirillum }+\mathrm{PSB}}$ & 25.64 & 110.87 & 75.63 & 22.83 & 23.98 \\
\hline $\begin{array}{l}\mathrm{T}_{5}-50 \% \mathrm{RDF}+50 \% \mathrm{~N} \text { as } \\
\text { FYM (8t/ha) }\end{array}$ & 24.41 & 107.87 & 73.67 & 26.33 & 22.63 \\
\hline $\mathrm{T}_{6}-100 \%$ NPK & 26.15 & 126.20 & 77.23 & 22.40 & 24.98 \\
\hline $\begin{array}{l}\mathrm{T}_{7-100 \%} \\
\mathrm{ZnSO} 4\end{array}$ & 26.56 & 145.67 & 78.10 & 20.15 & 26.17 \\
\hline $\mathrm{T}_{8^{-}} \mathbf{T}_{7}+$ residue recycling & 27.82 & 138.27 & 78.03 & 20.60 & 25.94 \\
\hline S.Em \pm & 0.672 & 6.303 & 1.520 & 1.275 & 0.513 \\
\hline $\mathrm{CD}(0.05)$ & 2.039 & 19.120 & NS & 3.869 & 1.557 \\
\hline$\overline{C V}$ & 4.529 & 8.948 & 3.460 & 9.606 & 3.661 \\
\hline
\end{tabular}


Table.2 Contd....

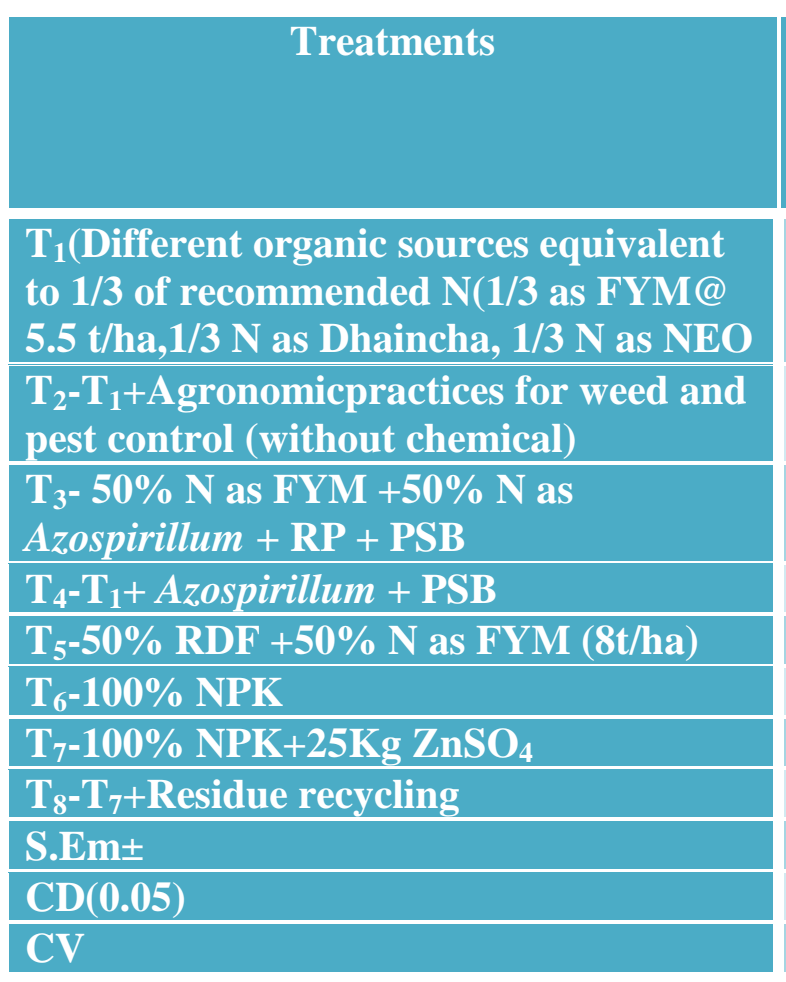

\begin{tabular}{|l|l|l|l|l|}
\hline $\begin{array}{l}\text { Straw } \\
\text { Yield } \\
\text { (t/ha) }\end{array}$ & $\begin{array}{l}\text { Grain } \\
\text { Yield with } \\
\text { chaff } \\
\text { (t/ha) }\end{array}$ & $\begin{array}{l}\text { Grain } \\
\text { Yield } \\
\text { without } \\
\text { chaff (t/ha) }\end{array}$ & $\begin{array}{l}\text { Harvest } \\
\text { Index }\end{array}$ & $\begin{array}{l}\text { Lodging } \\
(\%)\end{array}$ \\
\hline 5.61 & 6.5 & 5.1 & 0.476 & 13.33 \\
\hline 5.67 & 6.5 & 5.4 & 0.487 & 16.67 \\
\hline 4.95 & 5.8 & 4.4 & 0.470 & 15.00 \\
\hline 5.23 & 5.9 & 4.9 & 0.483 & 10.00 \\
\hline 5.5 & 5.9 & 5.0 & 0.476 & 43.33 \\
\hline 5.01 & 5.8 & 4.9 & 0.494 & 68.33 \\
\hline 5.78 & 7.5 & 6.1 & 0.513 & 86.67 \\
\hline 5.72 & 6.7 & 5.9 & 0.507 & 78.33 \\
\hline 0.004 & 0.120 & 0.048 & 0.001 & 6.474 \\
\hline 0.012 & 0.363 & 0.146 & 0.004 & 19.637 \\
\hline 0.131 & 3.273 & 1.599 & 0.438 & 27.048 \\
\hline
\end{tabular}

based on the use of inorganic chemical fertilizers to increase its productivity. However the use of such chemical fertilizers hampers the eco-system in general and soil quality in particular. As such there is an urgent need to focus more on the cultivation of rice organically and judicious use of recommended chemical fertilizers to increase its yield and to keep the eco-system intact. The present study focuses on the effect of organic manures and chemical fertilizers on the yield of rice seed (Oryza sativa). For the present study the rice variety 'lalat' has been chosen because of its widely used rice variety in Orissa as well its nutritional values.

From the study it has been found that seed yield of rice c.v. Lalat were enhanced due to various nutrient management practices. Between the organic sources of nutrients and inorganic fertilizers, the highest yield as well as other parameter were obtained from $\mathrm{T}_{7}(100 \% \mathrm{NPK}$ along with $25 \mathrm{~kg} \mathrm{ZnSO}_{4}$ ). 
In the present contest organic management practices of nutrient is considered to be suitable for maintaining a healthy ecosystem with a sustainable productivity. For quality seed production in rice due emphasis should be given on application of $\mathrm{N}$ in form of FYM and Dhaincha.

\section{References}

Arif, Muhammad, Muhammad Tasneem, Fiaz Bashir, Ghulam Yaseen, and Rana Muhammad Iqbal. "Effect of integrated use of organic manures and inorganic fertilizers on yield and yield components of rice." J. Agric. Res 52, no. 2 (2014): 197-206.

Feng, Y., L. Y. Cao, W. M. Wu, X. H. Shen, X. D. Zhan, R. R. Zhai, R. C. Wang, D. B. Chen, and S. H. Cheng. "Mapping QTLs for nitrogen- deficiency tolerance at seedling stage in rice (Oryza sativa L.)." Plant Breeding 129, no. 6 (2010): 652-656.

Gupta, Vikas, R. S. Sharma, and S. K. Vishwakarma. "Long-term effect of integrated nutrient management on yield sustainability and soil fertility of rice (Oryza sativa)-wheat (Triticum aestivum) cropping system." Indian Journal of Agronomy 51, no. 3 (2006): 160-164.

Ladha, Jagdish Kumar. Improving the productivity and sustainability of ricewheat systems of the Indo-Gangetic Plains: a synthesis of NARS-IRRI partnership research. No. 40. Int. Rice Res. Inst., 2000.

Mahesh, M. K., and S. P. Hosmani. "Morphological changes and nutrient uptake in some cultivars of rice treated with Bavistin." Journal of Ecotoxicology and Environmental Monitoring 14, no. 3 (2004): 195-198.

Niru, Kumari, Ashok Kumar Singh, S. K. Pal, and R. Thakur. "Effect of organic nutrient management on yield, nutrient uptake and nutrient balance sheet in scented rice (Oryza sativa)." Indian Journal of Agronomy 55, no. 3 (2010): 220-223.

Singh, G. R., K. S. Pandya, N. K. Chaure, S. S. Parihar, and K. K. Choudhary. "Soil fertility, productivity and profitability of rice under different organic manures." Oryza 37, no. 3 (2000): 208-212.

Singh, R. P., P. K. Singh, and A. K. Singh. "Effect of green manuring on physicochemical properties of soil and productivity of rice." ORYZA-An International Journal on Rice46, no. 2 (2009): 120-123.

Yadav, A. S., Ram Hardev, and M. K. Upadhyay. "Effect of nitrogen levels and plant geometry on growth, yield and root characteristics of hybrid rice (Oryza sativa)." Crop Research (Hisar) 40, no. 1/3 (2010): 16-19.

Yadav, D. S., Kumar Vineet, and Yadav Vivek. "Effect of organic farming on productivity, soil health and economics of rice (Oryza sativa)-wheat (Triticum aestivum) system." Indian Journal of Agronomy 54, no. 3 (2009): 267-271.

Yagoub, Samia Osman, Wigdan Mohamed Ali Ahmed, and A. A. Mariod. "Effect of urea, NPK and compost on growth and yield of soybean (Glycine max L.), in semi-arid region of Sudan." ISRN Agronomy 2012 (2012).

Yosef Tabar, S. "Effect of nitrogen and phosphorus fertilizer on growth and yield rice (Oryza sativa L.)." International journal of agronomy and Plant Production 3, no. 12 (2012): 579-584.

\section{How to cite this article:}

Naorem, L.C. 2018. Effect of Organic Manures and Chemical Fertilizers on the Yield of Rice Seed "Lalat". Int.J.Curr.Microbiol.App.Sci. 7(10): 2161-2166. doi: https://doi.org/10.20546/ijcmas.2018.710.248 